\title{
Structure-Activity Relationships of Cbx7 Inhibitors, Including Selectivity Studies against Other Cbx Proteins
}

Chakravarthi Simhadri, Michael C. Gignac, Cameron J. Anderson, Natalia Milosevich, Aman Dheri, Nishant Prashar, Robert T. Flemmer, Amarjot Dev, Trevor G. Henderson, Sarah F. Douglas, Jeremy E. Wulff, and Fraser Hof*

Department of Chemistry, University of Victoria, P.O. Box 3065, Victoria, British Columbia V8W 3V6, Canada

Supporting Information

ABSTRACT: The five human polycomb (Pc) paralog proteins, chromobox homolog (Cbx) $2 / 4 / 6 / 7 / 8$, are a family of chromodomain containing methyllysine reader proteins that are canonical readers of trimethyllysine 27 on histone 3 (H3K27me3). The aberrant expression of the $\mathrm{Cbx} 7$ gene is implicated in several cancers including prostate, gastric, thyroid, pancreas, and colon cancer. Previous reports on antagonizing the molecular recognition of $\mathrm{Cbx} 7-\mathrm{H} 3 \mathrm{~K} 27 \mathrm{me} 3$ with chemical inhibitors showed an impact on prostate cancer cell lines. We report here on the design, synthesis, and structure-activity relationships of a series of potent peptidomimetic antagonists that were optimized on a trimethyllysinecontaining scaffold to target $\mathrm{Cbx} 7$. The ligands were characterized using fluorescence polarization (FP) for their binding efficiency and selectivity against the Pc paralog Cbx proteins. The most selective ligand 9, as indicated by the FP


data analysis, was further characterized using the isothermal titration calorimetry (ITC). Compound 9 exhibits a $220 \mathrm{nM}$ potency for $\mathrm{Cbx} 7$ and exhibits 3.3, 1.8, 7.3 times selective for $\mathrm{Cbx} 7$ over $\mathrm{Cbx} 2 / 4 / 8$ and 28 -fold selective over the HP1 family member Cbx1. Our research provides several potent and partially selective inhibitors for Cbx2/4/7 that do not contain trimethyllysine. Our models and binding data suggest that the aromatic cages of $\mathrm{Cbx} 7 / \mathrm{Cbx} 4$ can accommodate larger alkyl groups such as diisobutyl substitution on the lysine nitrogen.

\section{INTRODUCTION}

Proteins that control the dynamic state of chromatin are critical in the epigenetic regulation of gene expression. ${ }^{1}$ One of the key mechanisms of the epigenetic control of chromatin is posttranslational modifications (PTMs) on histones. Methylation is among the most common PTMs on the histone side chains along with acetylation, phosphorylation, ubiquitylation, and glycosylation. ${ }^{2}$ Side chains of the lysine residues can be mono-, di-, or trimethylated. ${ }^{2 c, 3}$ Methylation of histone residues serves as a chemical switch to recruit effector protein complexes through methyl reader domains. The recruited proteins and multiprotein complexes influence the accessibility of DNA to transcriptional factors, which in turn regulate gene expression. The degree and the site of methylation determine which reader protein is recruited and ultimately the biological outcome, such as the activation or repression of gene expression. ${ }^{3}$

Methyllysine reader proteins have diverse roles in the development, cell-cycle regulation, and oncogenesis. ${ }^{4}$ Chromodomains are a family of methyllysine reader proteins that include the polycomb ( $\mathrm{Pc}$ ) paralog proteins, chromobox homolog ( $\mathrm{Cbx}$ ) 2/4/6/7/8, that recognize trimethyllysine 27 on histone 3 (H3K27me3). ${ }^{5}$ A closely related family, the heterochromatin protein 1 (HP1) paralogs consist of Cbx1/3/5 and recognize trimethyllysine 9 on histone 3. Pc group proteins play essential roles in the cell cycle control, maintenance of differentiation status during development, stem-cell self-renewal and maintenance, and cancer progression. ${ }^{6}$ The chromodomain of $\mathrm{Cbx} 7(\mathrm{ChD} \mathrm{Cbx} 7)$ has been the primary focus of biological research into the roles of Pc paralog proteins. The role of $\mathrm{Cbx} 7$ in disease pathogenesis is varied. Cbx7 plays a dual role as both an oncosuppressor and an oncogene, and its functions depend on cell specificity and tissue specificity and are defined by epigenetic factors such as interacting partners within the specific tissue environment. Upregulation of $\mathrm{Cbx} 7$ expression is observed in prostate, gastric, and lymphatic cancer. ${ }^{7}$ Conversely, reduced $\mathrm{Cbx} 7$ expression was shown to correlate with a high grade of tumors in thyroid, pancreatic, breast, colon, and lung carcinomas. ${ }^{8}$ Unlike in other cancers, the molecular basis of $\mathrm{Cbx} 7$ involvement in prostate cancer has been well established. Cbx7 epigenetically represses the INK4a/Arf locus through its chromodomain by binding to the long noncoding RNA ANRIL and H3K27me3 present at the locus. Disrupting the interactions of $\mathrm{H} 3 \mathrm{~K} 27 \mathrm{me} 3$ with $\mathrm{Cbx} 7$ by the mutagenesis of key residues diminishes the transcriptional repression of $\mathrm{Cbx} 7$ at the INK4a locus and has profound effects on the progrowth phenotype of $\mathrm{Cbx} 7$ expression in this model. In normal and prostate cancer cells, $\mathrm{Cbx} 7$ extends cellular life span and increases cell growth through the regulation of genes

Received: July 11, 2016

Accepted: September 23, 2016

Published: October 12, 2016 
a)

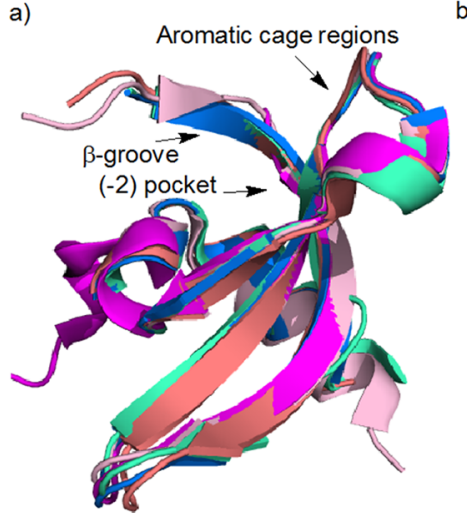

b)



c)

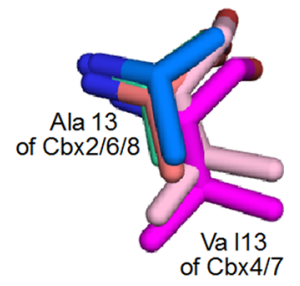

Figure 1. Structural similarities and differences among the chromodomains of Pc paralogs. (a) Overlay of Pc Cbx proteins. Cbx2 is shown in red (pdb code 3H91), Cbx4 in magenta (pdb code 38IZ), Cbx6 in marine blue (pdb code 3I90), Cbx7 in light pink (pdb code 4MN3), and Cbx8 in green ( $\mathrm{pdb}$ code 3I91). (b) Comparison of the aromatic cages of Pc Cbx proteins in the presence of their native ligand Kme3, with an exception for $\mathrm{Cbx} 4$ that does not have a cocrystal structure with the Kme3 side chain. (c) Overlay of residues lining the $(-2)$ pocket of Pc Cbx proteins. The figure was created using the PyMOL visualization software. ${ }^{12}$

at the Ink4a/Arf locus. ${ }^{9}$ In prostate cancer cell lines, Cbx7 downregulates p16 expression, leading to tumorgenesis. ${ }^{7 \mathrm{a}, \mathrm{b}, 9}$ Given the established role of $\mathrm{Cbx} 7$ in prostate cancer cells, chemical agents that selectively target the $\mathrm{ChD} \mathrm{Cbx} 7-$ $\mathrm{H} 3 \mathrm{~K} 27 \mathrm{me} 3$ interaction are proposed to be therapeutically beneficial.

Selectively targeting a single Pc paralog is challenging because of the high degree of sequence homology within the family (Figure 1a). ${ }^{5 \mathrm{~b}}$ The ligands are bound as the central strand in a three-stranded beta sheet. The binding pockets include an aromatic cage that binds the Kme3 residue, a small hydrophobic pocket that binds the residue, that is, the $\mathrm{N}$ terminal of two residues to the Kme3 ((-2) pocket), and a shallow, extended $\beta$-groove that accommodates the ligand residues from the $(-3)$ position onward.

The structural similarities and differences among chromodomains vary according to the binding subsites. The aromatic cage residues, Phe 11, Trp 32, and Trp 35, are highly conserved (Figure 1b). The Trp 35 in $\mathrm{Cbx} 2 / 4 / 6 / 7 / 8$ is replaced with the less-electron-rich phenylalanine residue in the HP1 family (not shown). This tryptophan/phenylalanine swap is a possible determinant for selectivity between the two families, in addition to the other structural differences distal to the aromatic cage that have been described. ${ }^{5 b}$ Efforts to make Cbx-selective inhibitors have therefore mainly depended on the $(-2)$ pocket and on the differences in the extended $\beta$-groove of the protein. The $(-2)$ pocket is buried under the side-chain-clasping bridge of the hydrophobic residues Val 10/Leu 49. These hydrophobic clasp residues (Val 10/Leu 49) of the Pc group are replaced with polar residues in HP1 (glutamic acid/aspartic acid). ${ }^{5 b}$ This switch influences the selectivity of the side chains of the residues at the $(-1)$ and $(-3)$ positions of the ligand. The floor of the $(-2)$ pocket is defined by Val 13 in $\mathrm{Cbx} 7 / \mathrm{Cbx} 4$, which is replaced by an Ala 13 residue that creates a larger $(-2)$ pocket in Cbx2/6/8 (Figure 1c). The HP1 paralogs Cbx1/3/5 also have a $\mathrm{Val} 13$ residue in the corresponding position (not shown). Substitution of a larger group in the $(-2)$ pocket was recently shown to confer good selectivity for Cbx6 over all other Pc and HP1 paralogs. ${ }^{10}$ Although significant structural differences exist in the extended $\beta$-groove portion of the $\mathrm{Cbx}$ proteins, little is known of how this region affects the selectivity among Cbx proteins. ${ }^{11}$
An additional challenge in targeting the Pc proteins is the induced-fit mechanism of the substrate binding. ${ }^{5 b, 13}$ Ligand-free structures for $\mathrm{Cbx}$ proteins are very different than the ligandbound structures for Cbx proteins (not shown). Whereas the H3K27me3-bound structures overlay very well (see Figure 1), the structures of $\mathrm{Cbx} 7$ cocrystallized with different inhibitors are more structurally divergent-especially in the ligandbinding aromatic cage region-demonstrating that the proteins can adopt multiple competent binding conformations. Probably for this reason, virtual screens have not yet yielded any chromodomain inhibitors. ${ }^{11}$

Successful approaches to $\mathrm{Cbx} 7$ inhibition have been driven by peptide-driven approaches or by high-throughput screening. We first reported on the $200 \mathrm{nM}$ peptidomimetic antagonists of $\mathrm{Cbx} 7,{ }^{11}$ which was followed by the development of a potent (97 nM) cell-active inhibitor UNC3866 by the Frye group. ${ }^{13 \mathrm{c}}$ Frye and James recently reported a one-bead-one-compound combinatorial approach that retargeted peptidic compounds toward the CDY family of chromodomains. ${ }^{14}$ The group of Zhou published an HTS-derived small-molecule inhibitor for Cbx7 with a $29 \mu \mathrm{M}$ affinity, and 3-fold and $>10$-fold selectivity over $\mathrm{Cbx} 4$ and $\mathrm{Cbx} 2 / 6 / 8$, respectively. The authors showed transcriptional derepression of the p16 gene in PC3 cancer cells upon their treatment with the inhibitor MS37452 at $500 \mu \mathrm{M}^{15}$ The weaker binding of MS37452 to Cbx7 is due to MS37452 occupying only two binding pocket subsites, the aromatic cage and the partly solvent-exposed $(-1)$ pocket of $\mathrm{Cbx} 7$. A followup report on an extended analog, engaging the hydrophobic $(-2)$ pocket, showed improved affinity.

We report here our own efforts to obtain an improved potency and selectivity for $\mathrm{Cbx} 7$. We used the existing peptidic scaffold for inhibitor development because it addresses all binding subpockets and because it has been demonstrated as the most potent cell-active tool against Cbx7. The ligand's alanine, which engages the $(-2)$ pocket, was maintained because we already showed separately that inhibitors with larger elements in this position lose affinity for $\mathrm{Cbx} 7$ and are reprogrammed for the selective inhibition of Cbx6. ${ }^{10,11} \mathrm{We}$ focused on two key binding regions that have limited a structure-activity relationship (SAR) established for potency and Cbx paralog selectivity: the aromatic cage and the extended $\beta$-groove. On the basis of the binding profiles and structural features of Cbx proteins, we hypothesized that targeting these 
regions would create agents with strong selectivity for $\mathrm{Cbx} 7$. In the end, we generated new SAR for agents that lean toward different subsets of members within the whole Pc family and that provided good selectivity over its closest relative $\mathrm{Cbx} 4$ but did not provide exclusive selectivity for $\mathrm{Cbx} 7$.

\section{RESULTS AND DISCUSSION}

We have established a fluorescence polarization (FP) assay using a panel of $\mathrm{Cbx}$ Pc proteins that include $\mathrm{Cbx} 2 / 4 / 6 / 7 / 8$ and the HP1 paralog Cbxl. These assays were initially developed with the native $\mathrm{H} 3 \mathrm{~K} 27 \mathrm{me} 3$ ligand, but the low inherent potency of this complex $\left(K_{\mathrm{d}}\right.$ values between 6 and 36 $\mu \mathrm{M}$ for different $\mathrm{Cbx}$ proteins: Table 1) made studies with

Table 1. Binding Affinities of the First- and SecondGeneration Dye-Labeled Probes with $\mathrm{Cbx}$ Proteins as Determined Using Direct FP ${ }^{a}$

\begin{tabular}{ccc} 
chromodomain & $\begin{array}{c}K_{\mathrm{d}} \text { for FITC-H3K27me3 } \\
\text { probe }(\mu \mathrm{M})^{b}\end{array}$ & $\begin{array}{c}K_{\mathrm{d}} \text { for second-generation } \\
\text { probe } 1(\mu \mathrm{M})^{c}\end{array}$ \\
\hline Cbx1 & $23 \pm 3.6$ & $5.5 \pm 0.54$ \\
Cbx2 & $5.8 \pm 0.2$ & $0.31 \pm 0.03$ \\
Cbx4 & $19 \pm 1.6$ & $0.21 \pm 0.01$ \\
Cbx6 & $36 \pm 4$ & $0.32 \pm 0.03$ \\
Cbx7 & $8.2 \pm 1.1$ & $0.09 \pm 0.10$ \\
Cbx8 & $30 \pm 4$ & $1.02 \pm 0.08$
\end{tabular}

${ }^{a}$ Binding data are obtained by titrating varied concentrations of $\mathrm{Cbx}$ proteins into a fixed concentration of the FITC-labeled probe. Data are the averages of two or three independent experimental trials and expressed as $K_{\mathrm{d}} \pm$ standard error in $\mu \mathrm{M}$. Solutions contain $20 \mathrm{mM}$ Tris, $250 \mathrm{mM} \mathrm{NaCl}, 1 \mathrm{mM}$ PMSF, $1 \mathrm{mM}$ benzamidine, and $0.01 \%$ Tween, at $\mathrm{pH}=8.0 .{ }^{b}[$ FITC $-\mathrm{H} 3 \mathrm{~K} 27 \mathrm{me} 3]=500 \mathrm{nM}$. Stock solution concentrations of Cbx1, 2, 4, 6, 7, and 8 are 450, 280, 800, 450, 175, and $760 \mu \mathrm{M}$, respectively. ${ }^{c}$ [Compound 1$]=100 \mathrm{nM}$. Stock solution concentrations of Cbx1, 2, 4, 6, 7, and 8 are 500, 500, 390, 500, 450, and $500 \mu \mathrm{M}$, respectively.

more potent compounds run against the tight-binding limit for the assay for some $\mathrm{Cbx}$ proteins, but not for other $\mathrm{Cbx}$ proteins. ${ }^{17}$ To enable competitive FP against the entire panel of proteins, we developed and used a probe (1), that is, a promiscuous binder across the whole test set of proteins (Figures 2 and 3$)^{10}$



Figure 2. Structure of probe used for the second-generation competitive FP assays.

Ligand-optimization efforts were initiated based on the core structure (2) (Figure 4). Compound 2 binds to $\mathrm{Cbx} 7$ with 0.22 $\mu \mathrm{M}$ potency and exhibited 2.1/3.9/9.1/30-fold selectivity against $\mathrm{Cbx} 2 / 4 / 6 / 8$, respectively and achieved a 36 -fold selectivity against HP1 homolog, Cbx1.

Replacements for the $\mathrm{N}$-terminal $p$-bromobenzamide group of $\mathbf{2}$ involved a selection of substituted benzoic acids. Tertiary amine replacements of the Kme3 group involved a variety of dialkyl substituents on the lysine nitrogen (Figure 4).

We envisioned that replacements to the $\mathrm{N}$-terminal group of the ligand that engages the extended $\beta$-groove would improve the potency and selectivity for Cbx7. We first explored changing the position of bromine on the $\mathrm{N}$-terminal phenyl group followed by substitution with different electron-donating, electron-withdrawing, and hydrophobic groups. Different choices of substituents were made to expand on the existing results by systematically exploring the substituent size, geometry, and chemistry. Synthesis was achieved on the solid phase, by treatment with different benzamides as the endcapping group (Scheme 1a). Selected replacements and binding affinities of the N-terminal group are presented in Table 2. The Supporting Information contains the synthesis and characterization data for all compounds.

The compounds were all tested by a competitive FP assay using probe 1 and recombinant, purified Cbx chromodomains (see the Supporting Information). $\mathrm{IC}_{50}$ values for the disruption of the $\mathrm{Cbx}$-probe complexes were determined using XLFit and are reported in Tables 2, 3, and 4.

Changing the bromo to the meta/ortho position of the $\mathrm{N}$ terminal phenyl group of 2 reduced the selectivity for $\mathrm{Cbx} 7$ and lowered the binding affinity to all $\mathrm{Cbx}$ proteins tested. The meta bromo substitution (3) lowered the binding affinity by 21 -fold for $\mathrm{Cbx} 7,5.1$-fold for $\mathrm{Cbx} 2$, and $\sim 2$-fold for $\mathrm{Cbx} 4 / 6$. The ortho bromo substitution (4) was detrimental for $\mathrm{Cbx} 7 / \mathrm{Cbx} 2$. Meta or ortho substitutions did not significantly influence binding to Cbx1/8. General potency trends observed for the bromosubstituted compounds to Cbx's is para > meta > ortho. Replacement of bromine with a methoxy group reduced the binding affinity to all $\mathrm{Cbx}$ proteins. All analogs with a methoxy substitution $(5,6$, and 7$)$ showed a decreased binding affinity to each $\mathrm{Cbx}$ protein, exhibiting the same trend as the bromo compounds (para > meta $>$ ortho). These results indicate that the bromine in the para position is making interactions with Cbx7 more favorably than it does with the other paralogs tested.

We hypothesized that the replacement of the $p$-bromophenyl group with the $p$-bromopyridinium group (11) would improve potency either by accepting a hydrogen bond from nearby donors or by tuning the electronics of the halogen. ${ }^{18}$ In doing so, compound 11 resulted in a 7.3-fold decrease in the potency for Cbx7, 6.6/5.0/4.4/3.5-fold decrease in the potency for $\mathrm{Cbx} 2 / 4 / 6 / 8$, respectively, and 1.5 -fold decrease in the potency for Cbxl.

Replacement of the para bromo group with an iodo or trifluoromethyl group showed reduced or abolished binding affinity to all Cbx's. Replacement with iodine (8) showed no binding to Cbx7. Replacement with $\mathrm{CF}_{3}(9)$ resulted in a small loss of potency up to 2-fold for each $\mathrm{Cbx}$ protein but showed a slightly improved selectivity for $\mathrm{Cbx} 7$ overall. Compound 9 showed a 2.7 -fold/9-fold selectivity for $\mathrm{Cbx} 7$ over $\mathrm{Cbx} 2 / 6$ and showed 36-fold selectivity over each of $\mathrm{Cbx} 1 / 8$. Compound 9 showed a 5.3 -fold selectivity for $\mathrm{Cbx} 7$ over $\mathrm{Cbx} 4$, which is the best selectivity achieved for any $\mathrm{Cbx} 7$ peptide-based antagonist against $\mathrm{Cbx} 4$ (the chromodomain that is most structurally similar to $\mathrm{Cbx} 7){ }^{11,13 c}$

Substitution with a hydrophobic tert-butyl group (10), as in UNC3866, improved the potency by $\sim 1.2$ fold to all Pc group Cbxs and showed a 3.1-fold loss to Cbxl. Compound 10 is the most potent compound for $\mathrm{Cbx} 7$, is 2.2-, 4.3-, 8.5-, and 28-fold 

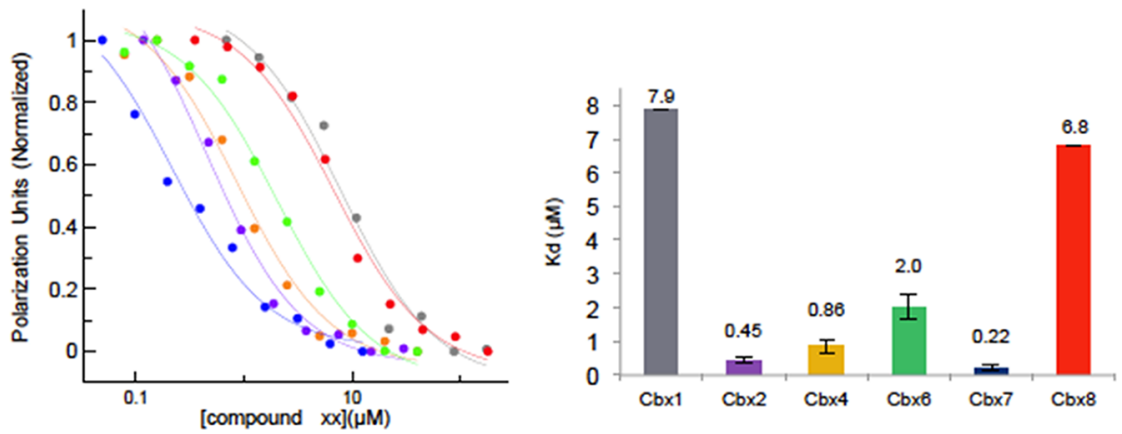

Figure 3. Binding data of compound 2 against a panel of Cbx proteins. Overlay of FP binding curves of the inhibitor 2 against a panel of Cbx proteins alongside the binding data presented as a bar graph. Gray $=\mathrm{Cbx} 1$, purple $=\mathrm{Cbx} 2$, yellow $=\mathrm{Cbx} 4$, green $=\mathrm{Cbx} 6$, blue $=\mathrm{Cbx} 7$, and red $=$ Cbx8. Data expressed as $\mathrm{IC}_{50} \pm$ standard errors.



Figure 4. Design of potent and selective Cbx7 inhibitors with N-terminus and Kme3 substitutions on the parent scaffold (2).

Scheme 1. Synthetic Routes to Prepare Peptidomimetics ${ }^{a}$

a)

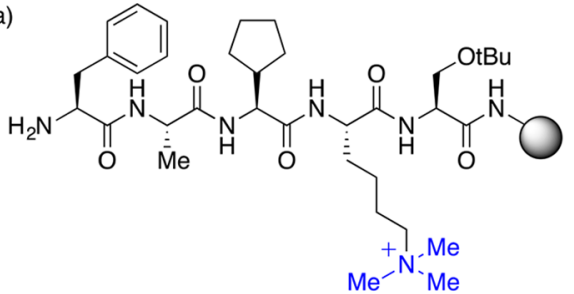

1) R-COOH, HBTU, DIPEA

DMF, Microwave

2) TFA cleavage, LCMS

Compounds 2-11

b)<smiles>[R11]NCCCC[C@H](NC(=O)[C@@H](COCC)NC(=O)[C@H](COC)NC(=O)[C@H](C)NC(=O)[C@H](Cc1ccccc1)N[R])C1CCCC1</smiles>

1) $5 \%$ TFA in dichloromethan

20 min each $\times 3$, room temp.

2) $\mathrm{R}^{1} \mathrm{CHO}, \mathrm{NaBH}_{3} \mathrm{CN}$, Acetic acid

DMF, 48 h, room temp.

3.TFA cleavage, LCMS

Compounds 12-16

a (a) Synthesis of N-terminal modifications of the scaffold and (b) synthesis of $\mathrm{N}$-alkylated peptidomimetics. 
Table 2. $\mathrm{IC}_{50}$ Data of $p$-Bromobenzamide Replacements of the Scaffold 2 for the Disruption of Cbx7-Compound 1 Complex ${ }^{a}$



${ }^{a}$ Binding data determined from the inhibitor concentration needed to half-dissociate the Cbx7-compound 1 complex. Data are the averages of two or three independent experimental trails and expressed as $\mathrm{IC}_{50} \pm$ standard error in $\mu \mathrm{M}$. FP data obtained upon titrating varied concentrations of inhibitors into a fixed concentration of Cbx protein and compound 1. Buffer used in the FP experiments is the same as reported in Table 1. The concentration of compound 1 is $100 \mathrm{nM}$. The concentrations used for Cbx1, 2, 4, 6, 7, and 8 are 10, 1, 1, 1, 0.4, and $7 \mu \mathrm{M}$ respectively. NA = not applicable, that is, compounds were not tested.

selective for $\mathrm{Cbx} 7$ over $\mathrm{Cbx} 2 / 4 / 6 / 8$, respectively, and is 140 fold selective for Cbx7 over Cbx1.

A variety of quaternary methylammonium group replacements were designed with varied size, hydrophobicity, and basicity to explore binding interactions to the aromatic cages of Cbx proteins (Figure 4). Synthesis of peptides 12-16 was achieved on the solid phase by $N$-alkylation following the Mtt deprotection of the lysine side chain without cleavage from the resin. A reductive amination was carried out with varying aldehydes added to the free lysine- $\varepsilon-\mathrm{NH}_{2}$ group (see Scheme $1 \mathrm{~b})$, and then the synthesis was completed by cleavage and purification as normal. The results for tertiary ammonium side chain replacements are shown in Table 3.

The dipropyl- and dibenyzl-lysine-containing compounds did not show binding to Cbxs. Compound $\mathbf{1 5}$ showed a very weak binding affinity, $>1000 \mu \mathrm{M}$, to Cbx7. No change in the FP signal was observed during the titration of 14 into $\mathrm{Cbx} 7$, which implies that the compound does not bind to Cbx7. Proteinprobe aggregation was a problem in these studies because of the poor solubility of the ligands, and this was noted particularly in titrations with $\mathrm{Cbx} 1 / 6 / 8$.

Of all replacements tested, the diethyllysine compound $\mathbf{1 2}$ was the best-tolerated replacement for the trimethyllysine (see Tables 3 and 4). Its binding affinity is less than that of the parent Kme3 compound by 1.5-3.6-fold across the panel. Compound 12 exhibited the strongest binding affinity to $\mathrm{Cbx} 7$, but when compared with the parent compound 2 , it was less selective for $\mathrm{Cbx} 7$ against most of the other Cbxs in the panel. The diisobutyl compound $\mathbf{1 3}$ showed a small decrease in the binding affinity to $\mathrm{Cbx} 7$ and a small increase in the binding affinity to $\mathrm{Cbx} 4$. Aggregation problems with $\mathrm{Cbx} 1 / 6 / 8$ prevented the determination of binding affinities and suggested that the solubility was not ideal. Compound $\mathbf{1 3}$ was the most potent $\mathrm{Cbx} 4$ inhibitor within the series but was not selective over Cbx7.

Combining the most selective $\mathrm{Cbx} 7 \mathrm{CF}_{3}$ group with the besttolerated Kme3 replacement (compound 16) resulted in a potent and partially selective $\mathrm{Cbx} 7$ inhibitor. Table 4 shows the 
Table 3. $\mathrm{IC}_{50}$ Data for the Disruption of Cbx7-Compound 1 Complex by N-Alkylated Lysine Replacements Based on Scaffold $2^{a}$



${ }^{a}$ Binding data determined from the inhibitor concentration needed to half-dissociate the complex of Cbx7-compound 1. Data are the averages of two or three independent experimental trails and expressed as $\mathrm{IC}_{50} \pm$ standard error in $\mu \mathrm{M}$. FP data is obtained upon titrating varied concentrations of inhibitors into a fixed concentration of Cbx protein and compound $\mathbf{1}$. Buffer and concentrations of compound $\mathbf{1}$ and Cbx protein are as reported in Table 2. NA = not applicable, that is, compounds were not tested. ND = not determined, that is, compounds were tested but because of the factors such as aggregation, $\mathrm{IC}_{50}$ values could not be determined.

Table 4. $\mathrm{IC}_{50}$ Data for the Disruption of Cbx7-Compound 1 Complex by Inhibitors with Both N-Terminal and N-Alkyl Substitutions on the Scaffold $2^{a}$

\begin{tabular}{|c|c|c|c|c|c|c|c|c|}
\hline Entry & $\begin{array}{l}\text { Lys } \\
\text { Alk }\end{array}$ & N-terminus & Cbxl & Cbx2 & $\mathrm{Cbx} 4$ & Cbx6 & Cbx7 & $\overline{C b x} 8$ \\
\hline 2 & $\begin{array}{l}\tilde{N}_{1} \\
\pm N \\
+N_{1}\end{array}$ & & $7.9 \pm 2$ & $\begin{array}{l}0.45 \pm \\
0.09\end{array}$ & $\begin{array}{l}0.86 \\
\pm 0.2\end{array}$ & $\begin{array}{l}2.0 \pm \\
0.3\end{array}$ & $\begin{array}{l}0.22 \pm \\
0.7\end{array}$ & $\begin{array}{l}6.8 \pm \\
1\end{array}$ \\
\hline 9 & $\underbrace{m}_{1}$ & & $11 \pm 2$ & $\begin{array}{l}0.80 \pm \\
0.2\end{array}$ & $\begin{array}{l}1.6 \pm \\
0.3\end{array}$ & $\begin{array}{l}2.7 \pm \\
0.3\end{array}$ & $\begin{array}{l}0.3 \pm \\
0.04\end{array}$ & $\begin{array}{l}11 \pm \\
2\end{array}$ \\
\hline 12 & $\begin{array}{c}\sim_{1}^{\prime} \\
+\stackrel{N}{H} \\
+\mathrm{H}\end{array}$ & & $15 \pm 4$ & $\begin{array}{l}1.5 \pm \\
0.3\end{array}$ & $\begin{array}{l}1.5 \pm \\
0.3\end{array}$ & $\begin{array}{l}3.1 \pm \\
0.5\end{array}$ & $\begin{array}{l}0.79 \pm \\
0.2\end{array}$ & $\begin{array}{l}13.1 \\
\pm 4\end{array}$ \\
\hline 16 & 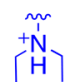 & & $19 \pm 6$ & $\begin{array}{l}1.5 \pm \\
0.4\end{array}$ & $\begin{array}{l}3.1 \pm \\
1\end{array}$ & $\begin{array}{l}5.7 \pm \\
0.8\end{array}$ & $\begin{array}{l}1.0 \pm \\
0.2\end{array}$ & $\begin{array}{l}12 \pm \\
2\end{array}$ \\
\hline
\end{tabular}

${ }^{a}$ Binding data determined from the inhibitor concentration needed to half-dissociate the Cbx7-compound 1 complex. Data are the averages of two or three independent experimental trails and expressed as $\mathrm{IC}_{50} \pm$ standard error in $\mu \mathrm{M}$. FP data obtained upon titrating varied concentrations of inhibitors into a fixed concentration of $\mathrm{Cbx}$ protein. Buffer and concentrations of compound 1, and Cbx protein concentrations are as reported in Table 2.

data for compound 16, along with those of its three most closely related parent compounds. Compound 16 registered generally lower potencies when compared with the trimethyllysine-containing parent compound (9) and also with the closely related diethyllysine analog (12). Compound 16 showed 1.5/ 3.1/5.7/12-fold selectivity for $\mathrm{Cbx} 7$ over $\mathrm{Cbx} 2 / 4 / 6 / 8$, respectively, and 19-fold selective over Cbxl.

Given the low selectivities ( $<10$-fold within the Pc group) of ligands by FP and variations in the concentration of each $\mathrm{Cbx}$ protein tested against the ligands, we sought to validate our FP findings using isothermal titration calorimetry (ITC) for one representative compound from each series, using the same recombinant $\mathrm{Cbx}$ constructs. $\mathrm{Cbx} 6$ poorly behaved at ITC concentrations and was omitted. We targeted compounds 9 and $\mathbf{1 6}$ for ITC titrations, each of which have a hydrophobic $\mathrm{CF}_{3}$ group that leads to strong binding. We could not perform ITC with 16 because at the working concentrations of ligand, we encountered solubility problems in either dissolving the compound or precipitation during the titration of inhibitor into protein. ITC data of compound 9 presented in Table 5 show that compound 9 binds to $\mathrm{Cbx} 7$ with a $K_{\mathrm{d}}$ value of $0.22 \mu \mathrm{M}$ and 3.3-, 1.8-, 7.3-fold selective for $\mathrm{Cbx} 7$ over $\mathrm{Cbx} 2 / 4 / 8$ and 28fold over Cbxl. Ligand-binding events with each $\mathrm{Cbx}$ protein registered favorable negative enthalpies and unfavorable entropies. There are strong signs of enthalpy-entropy compensation when comparing the binding of compound 9 to one protein or another, but we have insufficient structurefunction data to comment in detail on the thermodynamics of 
Table 5. ITC Binding Data for Compound 9 with Different Cbx Proteins ${ }^{a}$

$\begin{array}{ccccc}\text { protein } & K_{\mathrm{d}}(\mu \mathrm{M}) & \Delta H\left(\mathrm{~kJ} \mathrm{~mol}^{-1}\right) & -\mathrm{T} \Delta S\left(\mathrm{~kJ} \mathrm{~mol}{ }^{-1}\right) & \text { selectivity } \\ \text { Cbx1 } & 6.21 \pm 0.08 & -28.4 \pm 0.28 & -1.32 \pm 0.54 & 28 \\ \text { Cbx2 } & 0.73 \pm 0.32 & -21.3 \pm 0.97 & -14.0 \pm 2.12 & 3.3 \\ \text { Cbx4 } & 0.39 \pm 0.15 & -13.4 \pm 0.72 & -23.4 \pm 1.75 & 1.8 \\ \text { Cbx7 } & 0.22 \pm 0.02 & -22.4 \pm 0.01 & -15.7 \pm 0.62 & \\ \text { Cbx8 } & 1.61 \pm 0.01 & -6.42 \pm 0.002 & -26.7 \pm 0 & 7.3\end{array}$

${ }^{a}$ Average values are determined by ITC titrations in duplicate at $298 \mathrm{~K}$ in buffer, $20 \mathrm{mM}$ Tris, and $250 \mathrm{mM} \mathrm{NaCl}$ at $\mathrm{pH}=8$. binding across the series. Overall, the binding affinity trends of Cbx paralogs determined using FP and ITC are similar. There is a significant deviation between the $\mathrm{IC}_{50}$ and $K_{\mathrm{d}}$ values for Cbx8 and Cbx1. This is because of the weaker binding affinity of these proteins to probe peptide 1 , which ultimately leads to differences in the binding affinity determined using FP. Although probe peptide $\mathbf{1}$ is an improvement over earlier probes, with higher affinities that are relatively similar across the panel of Cbx proteins, these results suggest that FP data comparison in these studies is quantitative only for $\mathrm{Cbx}$ a)<smiles>CCN(CC)CCCC[C@H](NC(=O)[C@H](CC(C)C)NC(=O)[C@H](CO)NC(=O)[C@H](Cc1ccccc1)NC(=O)c1ccc(C(C)(C)C)cc1)C(=O)N[C@@H](Cc1ccccc1)C(=O)OC</smiles>

C)

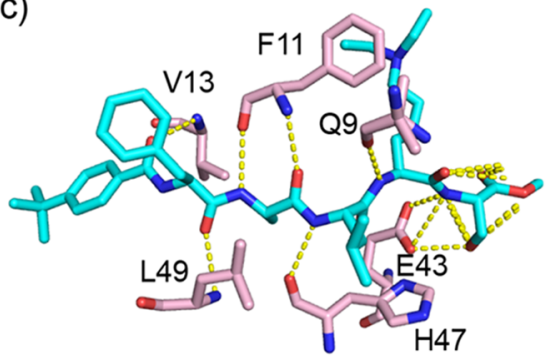

e)



g)

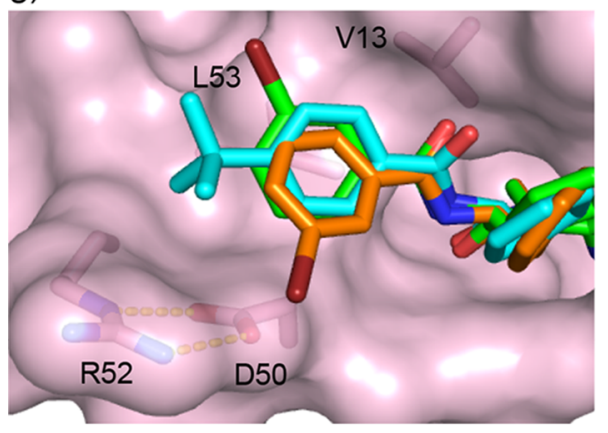

d) b)
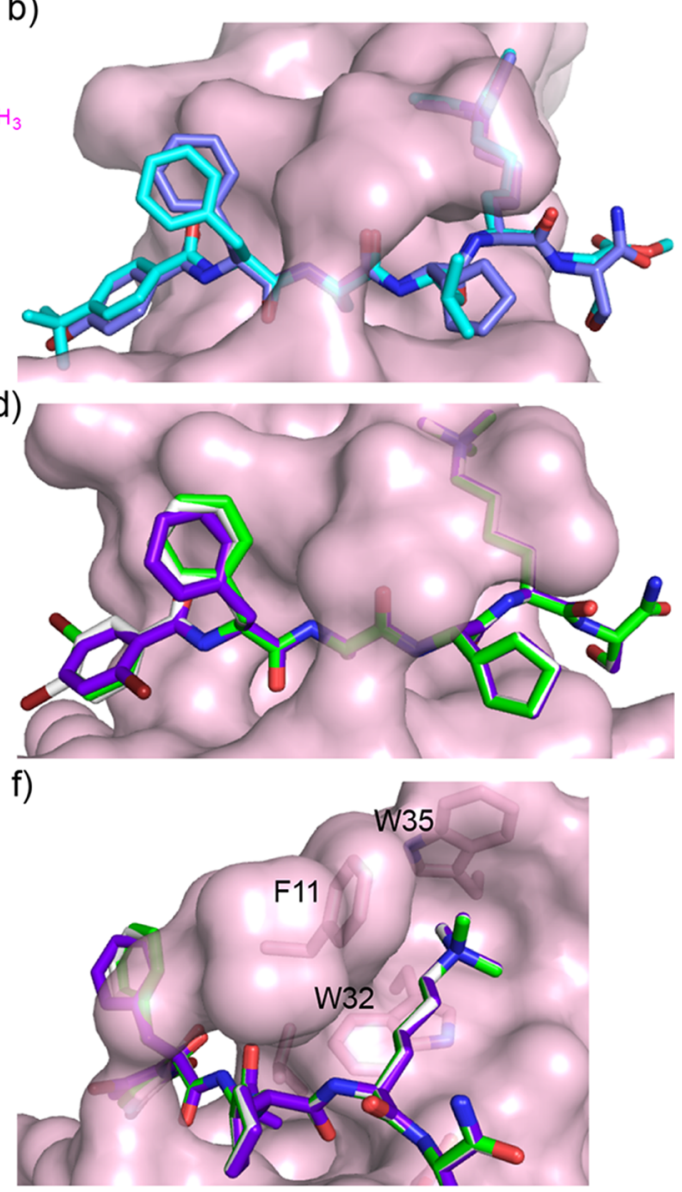

h)

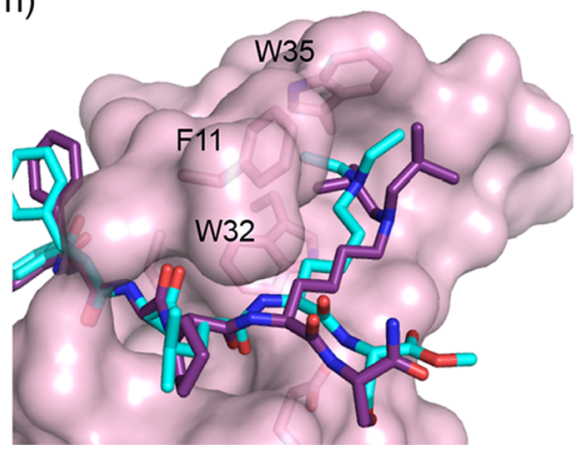

Figure 5. Understanding the binding affinities of inhibitors using molecular models. (a) Chemical structure of UNC3866. Key differences compared with compound 12 are highlighted in pink. (b) Overlay of compound 12 with UNC3866 in Cbx7. Cbx7 is shown in pink, UNC3866 in cyan, and compound 12 in slate blue (pdb code used for the model is 5EPJ). (c) Hydrogen bonding network between UNC3866 and Cbx7. (d) Overlay of para/meta/ortho bromo compounds in Cbx7. (Compounds 2, 3, and 4 are shown in gray white, green, and purple, respectively.) (e,f) Close-up views of the tert-butylbenzamide and diethyllysine portions of the ligands shown in panel $\mathrm{d}$. (g) Two possible meta orientations of the ligand 3. (h) Diisobutyl side chain of the ligand 13 within the aromatic cage of Cbx7 (compound 13 is shown in violet purple). The figure was created using the PyMOL visualization software. 
proteins and ligands in which the affinities are not near the tight-binding limit. ${ }^{17}$

The Frye group recently reported the $\mathrm{Cbx} 7$ inhibitor UNC3866, which is an analog of compound $\mathbf{2}$ and is similar to compounds 12 and $\mathbf{1 6}$ (Figure 5a). The key differences are methyl ester as the C-terminus, leucine side chain at the $(-1)$ position, and para t-butyl group at the N-terminus. To fully understand the SARs of our inhibitors, we carried out molecular modeling studies based on the X-ray cocrystal structures of the peptidic ligand Ac-FAYKme3S- $\mathrm{NH}_{2}$ with $\mathrm{Cbx} 7^{11}$ as well as UNC3866 with $\mathrm{Cbx} 2 / 4 / 7 / 8 .^{13 \mathrm{c}}$ The all-atom MAB force field as implemented in MOLOC was used for energy minimizations and qualitative comparisons. ${ }^{19}$ The cocrystal structures revealed that UNC3866 makes similar interactions with the chromodomains of $\mathrm{Cbx} 2 / 4 / 7 / 8$ at the $\mathrm{N}$-terminus, diethyllysine side chain, and the $\mathrm{C}$-terminus portions of the ligand. The energyminimized MOLOC model of the diethyllysine-containing compound, 12, was overlaid with UNC3866 in Cbx7, as shown in Figure $5 b$, and the model suggests that the backbones are highly aligned. Similar to that of Ac-FAYKme3S- $\mathrm{NH}_{2}$, the backbone of UNC3866 adopts a beta-strand conformation and is participating in an extensive backbone-to-backbone antiparallel $\beta$-sheet-like hydrogen-bonding network with the strands of $\mathrm{Cbx} 7$ on either side (Figure $5 \mathrm{c}$ ). The N-terminal tert-butylbenzamide portion of the ligand is partly embedded in a solvent-exposed cleft, which is formed by the Asp 50, Arg 52, and Leu 53 residues of the protein (Figure 5d). The shallow cleft is defined by one wall that is formed by a flat salt bridge between the side chains of Asp 50 and Arg 52. We conclude from the increasing potency in going from $\mathrm{MeO}$ to $\mathrm{Br}$ to $t$ - $\mathrm{Bu}$ ( 5 to 2 to 10), and also from the comparison of benzene versus pyridine ( 2 vs 11 ), that the hydrophobic interactions are of main importance for this binding element. The charged ArgAsp salt bridge would seem an unlikely platform for the hydrophobic interactions, but in fact the faces of such salt bridges have been demonstrated to be key hydrophobic-binding elements in model systems ${ }^{20}$ and in protein structural surveys. $^{21}$ The motif D-L-R in the extended $\beta$-groove of Pc proteins interacts with the tert-butylbenzamide group and is replaced by $\mathrm{C}-\mathrm{E} / \mathrm{D}-\mathrm{L}$ in the HP1 group. This swap abolishes the salt bridge present in the Pc proteins that contributes to the selectivity of inhibitors for Pc proteins against HP1 proteins.

The binding affinity results show that the para position is in the best orientation to be embedded in the extended $\beta$-groove of $\mathrm{Cbx}$ proteins. The models suggest that this simply minimizes steric repulsions that are introduced by substitutions at the ortho/meta positions (Figure $5 \mathrm{~d}-\mathrm{f}$ ). This explains higher potencies to all Cbxs for para-substituted compounds compared with those of the ortho-/meta-substituted analogs. The only exception to this rule in the whole data set is that the meta-substituted compound 6, which binds 1.6-fold stronger to $\mathrm{Cbx} 2$ than its para-substituted counterpart 5. The models show that one binding orientation for the meta-substituent in compound 3 could be directed away from the steric clashes with the cleft (Figure $5 \mathrm{~g}$ ), and we propose that this mode is more accessible for $\mathrm{Cbx} 2$ than for the other $\mathrm{Cbx}$ proteins.

The diethyllysine side chain is tolerated similarly in the aromatic cages of all $\mathrm{Cbx}$ proteins. The diethyllysine side chain of UNC3866 was first modeled and found to be favoring gauche conformation about the $\mathrm{C}_{\gamma}-\mathrm{C}_{\delta}$ bond when the ligand is bound to the $\mathrm{Cbx} 7 / \mathrm{Cbx} 8$ proteins. The high-resolution cocrystal structures ${ }^{13 c}$ confirmed the same conformation as observed with our ligands, as illustrated in Figure 5b. In UNC3866, one of the ethyl groups on the lysine $\varepsilon-\mathrm{NH}_{2}$ group interacts favorably with the aromatic pocket residues of $\mathrm{Cbx}$, whereas the other ethyl group is coming out of the pocket. In comparison to adapting $\mathrm{C}_{\gamma}-\mathrm{C}_{\delta}$ bond in anti conformation, adapting gauche conformation about the $\mathrm{C}_{\gamma}-\mathrm{C}_{\delta}$ bond shortens the side chain, which helps to minimize steric clashes in the aromatic cage. Accordingly, all diethyllysine peptide analogs in Table 3 maintain moderate potency to all $\mathrm{Cbx}$ proteins. Larger alkyl chains such as propyl (15), isobutyl (13), and benzyl groups (14) on lysine have comparatively more steric hindrance, explaining the reduction in binding affinity. The basicity of lysine nitrogen decreases in the order diethyllysine < dipropyllysine $<$ diisobutyllysine $<$ dibenzyllysine, which also negatively influences binding affinity in addition to the steric hindrance factor. Unexpectedly, the diisobutyl lysine containing compound 13 still holds some potency against $\mathrm{Cbx} 7$ and became relatively more potent for $\mathrm{Cbx} 4$. This can be explained by an energy-minimized model, which indicates that the binding affinity mostly comes from the hydrophobic interactions with one of the diisobutyl side chains of compound 13, and the loss in binding affinity is explained by the ammonium ion coming out of the aromatic cage because of the change in torsion angle of the lysine C-alpha (Figure 5h). The overall conclusion for this series of compounds is that the aromatic cage cannot be used as a source of selectivity among the Cbx paralogs.

\section{CONCLUSIONS}

We report on the inhibitors built from a lead scaffold (2) and selectivity studies against the five Pc paralog proteins. With a goal of achieving potency and selectivity for $\mathrm{Cbx} 7$ over $\mathrm{Cbx} 2 /$ $4 / 6 / 8$ and Cbx1, we synthesized two families of inhibitors by altering the $\mathrm{N}$-terminal and Kme3 groups of the scaffold. Potent submicromolar $\mathrm{Cbx} 7$ inhibitors with partial selectivity were synthesized. ITC data of compound 9 reveal that the compound binds to $\mathrm{Cbx} 7$ with a $K_{\mathrm{d}}$ value of $220 \mathrm{nM}$, with a $\sim 2-7$-fold of selectivity for $\mathrm{Cbx} 7$ over other Pc paralogs and $>25$-fold selectivity over HP1 paralog, Cbxl. The ITC data of compound 9 also reveal binding affinity trends that are in line with FP findings but also suggest some caution in interpreting selectivities obtained from the FP data quantitatively, especially where the probe peptide binds more weakly to its target (e.g., Cbx1 and Cbx8).

In spite of these limitations, some clear conclusions can be drawn from the FP data. Compounds $\mathbf{1 0}$ and $\mathbf{9}$ are $>4$-fold selective for $\mathrm{Cbx} 7$ over its closest relative $\mathrm{Cbx} 4$. The same two compounds show 2-5-fold selectivity across the series of human Pc paralogs and are very selective for $\mathrm{Cbx} 7$ over the HP1 paralog Cbxl (>30-fold and >100-fold, respectively). In addition to tuning the selectivity toward $\mathrm{Cbx} 7$, this series of studies showed some substitutions that tip the selectivity away from $\mathrm{Cbx} 7$ and toward other $\mathrm{Cbx}$ proteins. Compound $\mathbf{1 0}$ possesses a $t$-butyl group that achieves the highest potency (390 $\mathrm{nM}$ ) for Cbx2. Compound $\mathbf{1 3}$ contains a diisobutyl-substituted lysine side chain and was the most potent $\mathrm{Cbx} 4$ inhibitor (490 $\mathrm{nM})$.

FP is a powerful and convenient method for high-throughput screening and for detailed studies on the binding affinity across a panel of proteins. The tight-binding limit for FP probes is not a problem for the weaker-binding hits, but the advent of this entire class of submicromolar $\mathrm{Cbx}$ inhibitors requires the creation of even more potent FP probe ligands that are highly potent across all $\mathrm{Cbx}$ proteins. Because the tight-binding limit 
also applies to many other binding assays, such potent, promiscuous probes would be useful for a variety of $\mathrm{Cbx}$ targeted screening techniques.

This study did not produce a single compound that can exclusively bind $\mathrm{Cbx} 7$, but it does provide a set of compounds with different patterns of affinities in this important but scarcely explored family of targets. The inhibition of methyllysine reader proteins is in its infancy, but this can be considered analogous to the development of kinase inhibitors-almost none of them are exclusively selective for a single target, and yet their powerful biological activities arise from their patterns of selectivity in interesting ways. We will report on the cellbased studies of these inhibitors in due course.

\section{EXPERIMENTAL SECTION}

Materials. All N-Fmoc-protected natural and non-natural amino acids and Rink amide resin were purchased from ChemImpex International. Fmoc-L-Lys $(\mathrm{Me})_{3}-\mathrm{OH}$ was purchased from GL Biochem. Substituted benzoic acids used for making $\mathrm{N}$-terminal modifications were purchased from Sigma-Aldrich or Matrix Scientific. Aldehydes used for the synthesis of $\mathrm{N}$ alkylated lysine peptides were purchased from Sigma-Aldrich.

Peptide Synthesis. Peptide synthesis was carried out using Fmoc-solid-phase peptide synthesis protocols on Rink amide resin on a CEM Liberty 1 microwave peptide synthesizer. Peptides were synthesized at a $0.1 \mathrm{mmol}$ scale on Rink amide resin in dimethylformamide (DMF). Alternating cycles of Fmoc-deprotection, addition of Fmoc-amino acid, coupling reagent, and activator base were performed using default protocols of the instruments. Fmoc-deprotection was performed using $20 \%$ piperidine in DMF and amide coupling was performed using $1 H$-benzotriazol-1-yl[bis(dimethylamino)methylene]oxonium hexafluorophospate in DMF and $N, N$ diisopropylethylamine in $\mathrm{N}$-methyl-2-pyrrolidone.

All peptides were cleaved from resin by stirring with a solution of $95 \% \mathrm{TFA} / 2.5 \% d \mathrm{H}_{2} \mathrm{O} / 2.5 \%$ triisopropylsilane for 2 h. The resin was washed with trifluoroacetic acid (TFA) $(3 \mathrm{~mL}$, 3 times). The TFA solution was concentrated in vacuo, and the crude peptide was precipitated by the addition of cold, anhydrous diethyl ether. The diethyl ether solution was centrifuged for $10 \mathrm{~min}$ at $3700 \mathrm{rpm}$, and the diethyl ether was decanted. The crude peptide was dissolved in HPLC-grade $\mathrm{H}_{2} \mathrm{O} / \mathrm{MeCN}$ (concentrations dependent on the solubility of peptide, and dimethyl sulfoxide (DMSO) was added when the solubility was poor) and was purified using liquid chromatography-mass spectrometry (LC-MS).

All peptides were purified using LC-MS on preparative Luna C-18 column (Phenomenex, $5 \mu \mathrm{m}, 21.2 \times 250 \mathrm{~mm}^{2}$ ), using a detector wavelength channel of $254 \mathrm{nM}$. Peptides were purified by running a gradient from 90:10 0.1\% TFA in $\mathrm{H}_{2} \mathrm{O} / 0.1 \%$ TFA in $\mathrm{MeCN}$ to $10: 900.1 \%$ TFA in $\mathrm{H}_{2} \mathrm{O} / 0.1 \%$ TFA in $\mathrm{MeCN}$. Purity of peptides was determined using LC-MS on the Phenomenex Jupiter analytical column (Proteo, $4 \mu \mathrm{m}$ size particles, $250 \mathrm{~mm} 4.60 \mathrm{~mm}$ ). Peptides were characterized using low-resolution electrospray ionization-MS (LR-ESI-MS) and LC-MS.

Synthesis of N-Terminal Modification Peptides. Substituted benzoic acids were added to the N-terminal of the peptides on a CEM Liberty 1 microwave peptide synthesizer. Cleavage and purification were carried out as outlined in the above-mentioned general procedure for the peptide synthesis. Compounds 2-11 were synthesized in this fashion.
Synthesis of N-Alkylated Lysine Peptides. Syntheses of compounds 12-16 were achieved using the general procedure mentioned above. Lysine side-chain functionalization was carried out using a side-chain Mtt-protected lysine. Selective deprotection of lysine Mtt group on resin was achieved by stirring with a solution of $2 \% \mathrm{TFA} / 2 \%$ triisopropylsilane in dichloromethane $(\mathrm{DCM})(10 \mathrm{~mL}, 30 \mathrm{~min} \times 2)$, followed by stirring with a solution of $3 \% \mathrm{TFA} / 3 \%$ triisopropylsilane in DCM $(10 \mathrm{~mL}, 25 \mathrm{~min})$, and finally by stirring with a solution of $5 \% \mathrm{TFA} / 5 \%$ triisopropylsilane in DCM $(10 \mathrm{~mL}, 15 \mathrm{~min} \times 2)$. The resin was washed with $\mathrm{CH}_{2} \mathrm{Cl}_{2}(10 \mathrm{~mL} \times 3)$ after each treatment. $\mathrm{R}-\mathrm{CHO}$ (10-100 equiv), sodium cyanoborohydride $\left(\mathrm{NaBH}_{3} \mathrm{CN}\right)$ (10 equiv), glacial acetic acid (1 drop), and DMF $(10 \mathrm{~mL})$ were added to the peptide on resin and stirred at room temperature overnight. The resin was flushed and washed with DMF (10 mL, 3 times). Again, R-CHO (10-100 equiv), $\mathrm{NaBH}_{3} \mathrm{CN}$ (10 equiv), glacial acetic acid (1 drop), and DMF $(10 \mathrm{~mL})$ were added to the peptide on resin and stirred at room temperature overnight. The resin was washed with DMF $(10 \mathrm{~mL} \times 3)$ and then with $\mathrm{CH}_{2} \mathrm{Cl}_{2}(10 \mathrm{~mL} \times 3)$. Peptide cleavage from resin, purification, and characterization were performed as outlined above.

Protein Expression. BL21 CodonPlus RIL Eschericia coli cells (Stratagene) were transformed using Addgene plasmids 25245 (Cbx1), 25158 (Cbx2), 25237 (Cbx4), 25296 (Cbx6), 25241 ( $\mathrm{Cbx} 7)$, and a Cbx8 plasmid donated by Arrowsmith (Structural Genomics Consortium, Toronto, Canada). E. coli was grown at $37^{\circ} \mathrm{C}$ in $2 \mathrm{XYT}$ media to $\mathrm{OD} \approx 1.8$. Temperature was then dropped to $15{ }^{\circ} \mathrm{C}$ for $1 \mathrm{~h}$ and then induced with 1 mM IPTG (Life Technologies). Cultures were left shaking overnight and then pelleted, resuspended in binding buffer, and frozen the next day. The chromodomains of Cbx1 (20-73), Cbx2 (8-62), Cbx4 (8-65), Cbx6 (8-65), Cbx7 (8-62), and Cbx8 (8-61) were overexpressed as N-terminal HisX6-tagged proteins.

Protein Purification. E. coli was lysed by incubating on a rocker for $30 \mathrm{~min}$ with a $\mathrm{CHAPS} / \mathrm{dH}_{2} \mathrm{O}$ solution (Biobasic), followed by four short (10-15 s) rounds of sonication using a probe-tip sonicator. Centrifugation was subsequently performed to remove cell debris. The remaining supernatant was run through a nickel-nitrilotriacetic acid chelating column (Qiagen) and then through a Hiload 16/600 Superdex 75 pg size exclusion column (GE). The FP-LC step performed a buffer exchange into our "minimal" FP buffer consisting of 20 $\mathrm{mM}$ Tris $\mathrm{HCl}, 250 \mathrm{mM} \mathrm{NaCl}$, and $0.01 \%$ Tween-20. After concentrating protein to the desired concentration using Amicon centrifugal filter units, phenylmethane sulfonyl fluoride (PMSF), dithiothreitol (DTT), and benzamidine were added to a $1 \mathrm{mM}$ final concentration. Protein purity was assessed using SDS-PAGE gel. Cbx7 and $\mathrm{Cbx} 8$ histidine tags were removed after the nickel column step. Cleavage was performed overnight with our in-house TEV protease.

Direct Fluorescence Polarization Assay. Cbx1, 2, 4, 6, 7, and 8 proteins, at maximum concentrations ranging from $120-$ $800 \mu \mathrm{M}$, were titrated, in duplicate, into FITC-labeled H3K27me 3 or compound 1 at fixed concentrations of 500 and $100 \mathrm{nM}$, respectively. Both labeled probes were dissolved in distilled water and stored at $-20{ }^{\circ} \mathrm{C}$ until use. Cbx proteins with a low affinity to the particular probe had to be run at higher concentrations to acquire an accurate $K_{d}$ value. The assay was performed on 384-well black NUNC plates with optical bottoms. Each well contained a final volume of $50 \mu \mathrm{L}$ at the time of the read. The buffer used for the assay contained 20 
mM Tris-HCl pH 8.0, $250 \mathrm{mM} \mathrm{NaCl}, 1 \mathrm{mM}$ DTT, $1 \mathrm{mM}$ benzamidine, $1 \mathrm{mM}$ PMSF, and $0.01 \%$ Tween. After performing a serial dilution of $\mathrm{Cbx}$ proteins from right to left on a plate and leaving one buffer well (column 1 of plate) and one well with no Cbx (column 2 of plate), the plate was incubated in the dark for $15 \mathrm{~min}$ before being read. Plates were read with a SpectraMax M5 plate reader (molecular devices) with $\lambda_{\text {exc }} 450$ $\mathrm{nm}, \lambda_{\text {obs }} 530 \mathrm{~nm}$, and an instrument cutoff of $515 \mathrm{~nm}$. The FP read yielded values for parallel $(S)$ and perpendicular $(\mathrm{P})$ light emission.

Competitive Fluorescence Polarization Assay. The competitive assay was performed in duplicate using 96-well black plates (NUNC). Compound $\mathbf{1}$ was dissolved in water and stored at $-20{ }^{\circ} \mathrm{C}$ until use. The buffer used for the assay contained $20 \mathrm{mM}$ Tris- $\mathrm{HCl} \mathrm{pH} 8.0,250 \mathrm{mM} \mathrm{NaCl}, 1 \mathrm{mM}$ DTT, $1 \mathrm{mM}$ benzamidine, $1 \mathrm{mM}$ PMSF, and $0.01 \%$ Tween. Various concentrations of inhibitors dissolved in water $(\mathrm{N}$ alkylated lysine compounds needed up to maximum $10 \%$ DMSO to completely dissolve) were titrated into a set concentration of compound $1(100 \mathrm{nM})+\mathrm{Cbx}$ protein of interest ( $\mathrm{Cbx} 1,2,4,6,7$, and 8). The maximum concentration that the inhibitor was titrated at varied from $1.2 \mathrm{mM}$ to $10 \mu \mathrm{M}$. The set concentrations for Cbx proteins were $10 \mu \mathrm{M}$ (Cbx1), 1 $\mu \mathrm{M}$ (Cbx2, 4, and 6), $0.4 \mu \mathrm{M}$ (Cbx7), and $7 \mu \mathrm{M}$ (Cbx8). All wells had a final volume of $100 \mu \mathrm{L}$. Plates were incubated in the dark for $15 \mathrm{~min}$ after the dilutions. The reads and data analysis were performed in the same manner as for direct FP. Many of the inhibitors required up to $10 \%$ DMSO to properly dissolve. Separate competitive FP assays were performed with a known medium strength binder of $\mathrm{Cbx} 7$ titrated into compound $\mathbf{1}+$ Cbx7, with the inhibitor dissolved in various percentages of DMSO. This assay showed that the $10 \%$ DMSO would be tolerated without significantly affecting the $\mathrm{IC}_{50}$ values (data not shown).

Fluorescence Polarization Data Analysis. Microsoft Excel was used to determine the averaged $\mathrm{P}$ and $\mathrm{S}$ values, minus values for buffer control wells, for each data point. Millipolarization $(\mathrm{mP})$ units were calculated using the formula $[(\mathrm{S}-\mathrm{P}) /(\mathrm{S}+\mathrm{P})] \times 1000$, and the resulting data were plotted with a curve-fitting add-in for Excel (XLFit) using the equation $\left\{C+\left[\left(\mathrm{BL}_{\max } \times x\right) /\left(K_{\mathrm{d}}+x\right)\right]\right\}$. In some instances, the data points for the highest inhibitor concentrations had to be excluded where the points had abnormally high $\mathrm{mP}$ due to aggregation.

Isothermal Titration Calorimetry. Cbx proteins were dialyzed into ITC buffer $(20 \mathrm{mM}$ Tris, $250 \mathrm{mM} \mathrm{NaCl}, \mathrm{pH}=$ 8.0), and the concentrations of proteins were measured at $\mathrm{A} 280$ using absorbance spectroscopy. The dialysis buffer solution was used to dilute the proteins and to dissolve the inhibitor 9. ITC experiments were conducted at $298 \mathrm{~K}$ using MicroCal VP-ITC. The ligand solution $(40-60 \mathrm{mM})$ in syringe was titrated into the Cbx protein $(16-48 \mu \mathrm{M})$ in a sample cell. Each titration contains 30 injections, with the first injection measuring $2 \mu \mathrm{L}$ and remaining injections measuring $10 \mu \mathrm{L}$ each. The duration between two consecutive injections was $240 \mathrm{~s}$. Control titration of heat from ligand dilution was measured from a titration of the ligand solution into the buffer with the above-mentioned instrument settings. Data treatment of titrations to obtain thermodynamic parameters was performed as follows: baseline corrections were performed for both the main titration and control titration data, control data were subtracted from the main data, and data fitting was carried out with a OneSites binding model using the Origin data-fitting software.
Thermodynamic parameters presented in Table 5 are the mean values from two individual runs.

\section{ASSOCIATED CONTENT}

\section{Supporting Information}

The Supporting Information is available free of charge on the ACS Publications website at DOI: 10.1021/acsomega.6b00120.

Compound characterization by LC-MS, FP, and ITC data (PDF)

\section{AUTHOR INFORMATION}

\section{Corresponding Author}

*E-mail: fhof@uvic.ca.

\section{Notes}

The authors declare no competing financial interest.

\section{ACKNOWLEDGMENTS}

This work was funded by the West Coast Ride to Live, Prostate Cancer Canada, and Cancer Research Society of Canada. J.E.W. and F.H. are Canada Research Chairs.

\section{ABBREVIATIONS}

Cbx, chromobox homolog; ITC, isothermal titration calorimetry; PTM, posttranslational modifications; PRC1/2, polycomb repressive complex-1/2; Pc, polycomb; HP1, heterochromatin protein 1; $\mathrm{H} 3 \mathrm{~K} 27 \mathrm{me} 3$, histone 3 lysine 27 trimethylated; H3K9me3, histone 3 lysine 9 trimethylated; ANRIL, a noncoding RNA in the INK4 locus; FP, competitive fluorescence polarization; $\mathrm{H} 3 \mathrm{~K} 27 \mathrm{me} 3$, histone 3 lysine 27 trimethylated; HBTU, 1 H-benzotriazol-1-yl[bis(dimethylamino)methylene] oxonium hexafluorophospate; DIPEA, $N, N$-diisopropylethylamine; $\mathrm{NaBH}_{3} \mathrm{CN}$, sodium cyanoborohydride

\section{REFERENCES}

(1) Rothbart, S. B.; Strahl, B. D. Interpreting the language of histone and DNA modifications. Biochim. Biophys. Acta, Gene Regul. Mech. 2014, 1839, 627-643.

(2) (a) Jenuwein, T.; Allis, C. D. Translating the histone code. Science 2001, 293, 1074-1080. (b) Strahl, B. D.; Allis, C. D. The language of covalent histone modifications. Nature 2000, 403, 41-45. (c) Musselman, C. A.; Khorasanizadeh, S.; Kutateladze, T. G. Towards understanding methyllysine readout. Biochim. Biophys. Acta, Gene Regul. Mech. 2014, 1839, 686-693.

(3) Martin, C.; Zhang, Y. The diverse functions of histone lysine methylation. Nat. Rev. Mol. Cell Biol. 2005, 6, 838-849.

(4) (a) Wagner, T.; Robaa, D.; Sippl, W.; Jung, M. Mind the methyl: Methyllysine binding proteins in epigenetic regulation. ChemMedChem 2014, 9, 466-483. (b) Greer, E. L.; Shi, Y. Histone methylation: A dynamic mark in health, disease and inheritance. Nat. Rev. Genet. 2012, 13, 343-357. (c) Milosevich, N.; Hof, F. Chemical Inhibitors of Epigenetic Methyllysine Reader Proteins. Biochemistry 2016, 55, 1570-1583. (d) James, L. I.; Frye, S. V. Chemical probes for methyl lysine reader domains. Curr. Opin. Chem. Biol. 2016, 33, 135-141.

(5) (a) Blus, B. J.; Wiggins, K.; Khorasanizadeh, S. Epigenetic virtues of chromodomains. Crit. Rev. Biochem. Mol. Biol. 2011, 46, 507-526. (b) Kaustov, L.; Ouyang, H.; Amaya, M.; Lemak, A.; Nady, N.; Duan, S.; Wasney, G. A.; Li, Z.; Vedadi, M.; Schapira, M.; Min, J.; Arrowsmith, C. H. Recognition and specificity determinants of the human Cbx chromodomains. J. Biol. Chem. 2011, 286, 521-529.

(6) (a) Gieni, R. S.; Hendzel, M. J. Polycomb group protein gene silencing, non-coding RNA, stem cells, and cancer. Biochem. Cell Biol. 2009, 87, 711-746. (b) Klauke, K.; Radulović, V.; Broekhuis, M.; Weersing, E.; Zwart, E.; Olthof, S.; Ritsema, M.; Bruggeman, S.; Wu, 
X.; Helin, K.; Bystrykh, L.; de Haan, G. Polycomb Cbx family members mediate the balance between haematopoietic stem cell selfrenewal and differentiation. Nat. Cell Biol. 2013, 15, 353-362.

(7) (a) Bernard, D.; Martinez-Leal, J. F.; Rizzo, S.; Martinez, D.; Hudson, D.; Visakorpi, T.; Peters, G.; Carnero, A.; Beach, D.; Gil, J. CBX7 controls the growth of normal and tumor-derived prostate cells by repressing the Ink4a/Arf locus. Oncogene 2005, 24, 5543-5551. (b) Aguilo, F.; Zhou, M.-M.; Walsh, M. J. Long noncoding RNA, polycomb, and the ghosts haunting INK4b-ARF-INK4a expression. Cancer Res. 2011, 71, 5365-5369. (c) Zhang, X.-W.; Zhang, L.; Qin, W.; Yao, X.-H.; Zheng, L.-Z.; Liu, X.; Li, J.; Guo, W.-J. Oncogenic role of the chromobox protein CBX7 in gastric cancer. J. Exp. Clin. Cancer Res. 2010, 29, 114. (d) Scott, C. L.; Gil, J.; Hernando, E.; TeruyaFeldstein, J.; Narita, M.; Martinez, D.; Visakorpi, T.; Mu, D.; CordonCardo, C.; Peters, G.; Beach, D.; Lowe, S. W. Role of the chromobox protein CBX7 in lymphomagenesis. Proc. Natl. Acad. Sci. U.S.A. 2007, 104, 5389-5394.

(8) (a) Pallante, P.; Federico, A.; Berlingieri, M. T.; Bianco, M.; Ferraro, A.; Forzati, F.; Iaccarino, A.; Russo, M.; Pierantoni, G. M.; Leone, V.; Sacchetti, S.; Troncone, G.; Santoro, M.; Fusco, A. Loss of the CBX7 gene expression correlates with a highly malignant phenotype in thyroid cancer. Cancer Res. 2008, 68, 6770-6778. (b) Karamitopoulou, E.; Pallante, P.; Zlobec, I.; Tornillo, L.; Carafa, V.; Schaffner, T.; Borner, M.; Diamantis, I.; Esposito, F.; Brunner, T.; Zimmermann, A.; Federico, A.; Terracciano, L.; Fusco, A. Loss of the $\mathrm{CBX} 7$ protein expression correlates with a more aggressive phenotype in pancreatic cancer. Eur. J. Cancer 2010, 46, 1438-1444. (c) Meseure, D.; Vacher, S.; Alsibai, K. D.; Nicolas, A.; Chemlali, W.; Caly, M.; Lidereau, R.; Pasmant, E.; Callens, C.; Bieche, I. Expression of ANRIL-Polycomb Complexes-CDKN2A/B/ARF Genes in Breast Tumors: Identification of a Two-Gene (EZH2/CBX7) Signature with Independent Prognostic Value. Mol. Cancer Res. 2016, 14, 623-633. (d) Pallante, P.; Terracciano, L.; Carafa, V.; Schneider, S.; Zlobec, I.; Lugli, A.; Bianco, M.; Ferraro, A.; Sacchetti, S.; Troncone, G.; Fusco, A.; Tornillo, L. The loss of the CBX7 gene expression represents an adverse prognostic marker for survival of colon carcinoma patients. Eur. J. Cancer 2010, 46, 2304-2313. (e) Forzati, F.; Federico, A.; Pallante, P.; Abbate, A.; Esposito, F.; Malapelle, U.; Sepe, R.; Palma, G.; Troncone, G.; Scarfò, M.; Arra, C.; Fedele, M.; Fusco, A. CBX7 is a tumor suppressor in mice and humans. J. Clin. Invest. 2012, 122, 612623.

(9) Gil, J.; Bernard, D.; Martínez, D.; Beach, D. Polycomb CBX7 has a unifying role in cellular lifespan. Nat. Cell Biol. 2004, 6, 67-72.

(10) Milosevich, N.; Gignac, M. C.; McFarlane, J.; Simhadri, C.; Horvath, S.; Daze, K. D.; Croft, C. S.; Dheri, A.; Quon, T. T. H.; Douglas, S. F.; Wulff, J. E.; Paci, I.; Hof, F. Selective Inhibition of CBX6: A Methyllysine Reader Protein in the Polycomb Family. ACS Med. Chem. Lett. 2016, 7, 139-144.

(11) Simhadri, C.; Daze, K. D.; Douglas, S. F.; Quon, T. T. H.; Dev, A.; Gignac, M. C.; Peng, F.; Heller, M.; Boulanger, M. J.; Wulff, J. E.; Hof, F. Chromodomain antagonists that target the polycomb-group methyllysine reader protein chromobox homolog 7 (CBX7). J. Med. Chem. 2014, 57, 2874-2283.

(12) The PyMol Molecular Graphics System; Version v1.8.0.5; Schrodinger, LLC; 2016.

(13) (a) Taverna, S. D.; Li, H.; Ruthenburg, A. J.; Allis, C. D.; Patel, D. J. How chromatin-binding modules interpret histone modifications: Lessons from professional pocket pickers. Nat. Struct. Mol. Biol. 2007, 14, 1025-1040. (b) Yap, K. L.; Zhou, M.-M. Structure and mechanisms of lysine methylation recognition by the chromodomain in gene transcription. Biochemistry 2011, 50, 1966-1980. (c) Stuckey, J. I.; Dickson, B. M.; Cheng, N.; Liu, Y.; Norris, J. L.; Cholensky, S. H.; Tempel, W.; Qin, S.; Huber, K. G.; Sagum, C.; Black, K.; Li, F.; Huang, X.-P.; Roth, B. L.; Baughman, B. M.; Senisterra, G.; Pattenden, S. G.; Vedadi, M.; Brown, P. J.; Bedford, M. T.; Min, J.; Arrowsmith, C. H.; James, L. I.; Frye, S. V. A cellular chemical probe targeting the chromodomains of Polycomb repressive complex 1. Nat. Chem. Biol. 2016, 12, 180-187.
(14) Barnash, K. D.; Lamb, K. N.; Stuckey, J. I.; Norris-Drouin, J. L.; Cholensky, S. H.; Kireev, D. B.; Frye, S. V.; James, L. I. Chromodomain Ligand Optimization via Target-Class Directed Combinatorial Repurposing. ACS Chem. Biol. 2016, 11, 2475-2483.

(15) Ren, C.; Morohashi, K.; Plotnikov, A. N.; Jakoncic, J.; Smith, S. G.; Li, J.; Zeng, L.; Rodriguez, Y.; Stojanoff, V.; Walsh, M.; Zhou, M.M. Small-molecule modulators of methyl-lysine binding for the CBX7 chromodomain. Chem. Biol. 2015, 22, 161-168.

(16) Ren, C.; Smith, S. G.; Yap, K.; Li, S.; Li, J.; Mezei, M.; Rodriguez, Y.; Vincek, A.; Aguilo, F.; Walsh, M. J.; Zhou, M.-M. Structure-Guided Discovery of Selective Antagonists for the Chromodomain of Polycomb Repressive Protein CBX7. ACS Med. Chem. Lett. 2016, 7, 601-605.

(17) Huang, X. Fluorescence polarization competition assay: The range of resolvable inhibitor potency is limited by the affinity of the fluorescent ligand. J. Biomol. Screening 2003, 8, 34-38.

(18) Wilcken, R.; Zimmermann, M. O.; Lange, A.; Zahn, S.; Boeckler, F. M. Using halogen bonds to address the protein backbone: A systematic evaluation. J. Comput.-Aided Mol. Des. 2012, 26, 935-945.

(19) Gerber, P. R.; Müller, K. MAB, a generally applicable molecular force field for structure modelling in medicinal chemistry. J. Comput.Aided Mol. Des. 1995, 9, 251-268.

(20) (a) Thompson, S. E.; Smithrud, D. B. Carboxylates stacked over aromatic rings promote salt bridge formation in water. J. Am. Chem. Soc. 2002, 124, 442-449. (b) Wang, X.; Post, J.; Hore, D. K.; Hof, F. Minimalist synthetic host with stacked guanidinium ions mimics the weakened hydration shells of protein-protein interaction interfaces. J. Org. Chem. 2014, 79, 34-40.

(21) Crowley, P. B.; Golovin, A. Cation $-\pi$ interactions in proteinprotein interfaces. Proteins: Struct., Funct., Bioinf. 2005, 59, 231-239. 